\title{
The Impact of Supervision, Motivation and Work Ethic on Teachers' Professional Competence: A Case Study of Private Islamic High School Teachers
}

\author{
Muhammad Idris \\ Department of Management, Faculty of Economics and Business \\ Universitas Muhammadiyah Palembang, Indonesia \\ Email: idris_ump@yahoo.co.id
}

Received: February 01, 2016 Accepted: February 24, 2016 Published: March 15, 2016

doi:10.5296/ijhrs.v6i1.9073 URL: http://dx.doi.org/10.5296/ijhrs.v6i1.9073

\begin{abstract}
This study aims to investigate the impact of supervision, motivation and work ethic on teachers' professional competence. Using a sample of 131 respondents, and all respondents are teachers of SMA Muhammadiyah in East OKU, South Sumatera, Indonesia; and this study employs an Ordinary Least Square (OLS) method. All variables, apart from motivation exhibit a positive and significant impact on teachers' professional competence. Meanwhile, motivation has no impact on teachers' professional competence. It can be concluded that an education institution who have more strict supervision will have higher teachers' professional competence and teachers who have higher work ethic will improve teachers' professional competence.
\end{abstract}

Keywords: Supervision, Motivation, Work ethic, Teachers' professional competence, Human resource, Education sector, Indonesia 


\section{Introduction}

Education is one of pillars to build a nation, and it will also determine the quality of nation. Therefore it is important to strenghten the education in one country through education management. The success of an educational institution lies on applied management practices. Teachers are a part of education system, as they plays a vital role to shape current and future generations, and hence, improving the quality of teachers is an urgent matter. According to Act No. 14/2005 Article 1 stated that teachers should comply to a professionalims requirements as they main tasks are educating, teaching, guiding, directing, training, assessing and evaluating students. As professional teacher, they should posses an adequate competency, so that they are able to demonstrate a number of strategies and approaches in teaching and learning process accroding to teachers' code of conduct. Further, according to government regulation No.74/2008 Article 3, p (7) stated that professional competency of teachers is interpreted as a broad and deep understanding of science, technology, art and culture in accord with their field and met the minimum standard of teachers' professionalism requirements. In addition, competence can defined as fusion of knowledge (cognitive), attitudes (power heart) and skills (physical power) in the form of actions which must be owned by a teacher to carry out professional duties. Therefore, it can be concluded that there are few factors affecting teachers' professional competence.

One of the intrinsic factors that may also increase the professional competence of teachers is motivation. Motivation according to Siswanto (2007) as the state of the human psyche and the mental attitude that gives energy, encouraging activities (moves), and a lead or channeled towards achieving behavior needs to give satisfaction. Motivation is very important in themselves as teacher. Motivated teachers would be expected to work hard and enthusiastically to achieve high labor productivity. Professional development of teachers will be maximised if it is supported by a highly motivated principals. Motivation is very important for every person to work hard because of the desire to excel from others.

One of the challenges faced by Indonesian education sector is the lack of qualified educators both teachers and lecturers and, hence, the government attempted to overcome this barrier by enacting a number of key policies to raise the status and quality of teachers (OECD, 2015). One of the most significant policies is Act No. 14/2005 stated that teaching as a profession, and therefore higher degree qualification is required. A certification is one way to eliminate the quality problem of teachers by providing professional allowances, and this professional allowance will allow them to afford the average of living standard. According to Ministry of Education Regulation (Permendikbud) No. 5/2012, Article 5 stated about certification as a part of teachers assessment portfolio which includes a testimony professional competence experience of teachers. The certification required : 1) Academic qualifications, 2) Education and training , 3) Teaching experience, 4) Planning and the implementation of learning, 5) Assessment of superiors and supervisors, 6) Academic performance, 7) Professional development work, 8) Participation in scientific forums. In addition, certification requires a teachers' portfolios of evidence or a 90-day course. The portfolio contains reflection of previous and agenda of future activities, and they will not pass the certification if only portfolio contains courses attended and certificates gained. Most teachers merely fill portfolio 
according to the minimum standard required, hence it will not provide sufficient information of their capability/competence so that they may be able to improve their performance in future.

It is also expected that certification will also be able to upgrade students outcomes in which certified teachers have the capacity and skills needed to engage with students. To support this expectation, therefore supervision, motivation and work ethic are required for teachers. Barber and Mourshed (2009) asserted that continuous improvement of teachers'slills and knowledge will affect the world-class education system. Therefore, an effective assesment do not solely rely on teachers' explicit performance but also rely on teachers' implisit performance as it is a part of professional development opportunities for them.

Barber and Mourshed (2007) asserted that the quality of teachers will determine the quality of an education system. Schools are an integral part of the community, and there is also interdependence between the school and the community. School social institutions that serve education will encourage the public school progress according to expectations. Teachers' content knowledge, teachers' pedagogical knowledge, teaching practices supported by the effective classroom management and individualised instruction, a commitment to higher-order problem solving, deep analysis of content, and activities requiring advanced thinking skills and deductive reasoning, and active professional collaboration that has a direct impact on learning and teaching are key aspects of effective teaching and these key elements include classroom observations, team teaching and constructive feedback (OECD, 2009).

Further, Educational leadership is very important in Indonesia in which high-quality leadership and supervision is required to improve teaching practice and student outcomes (OECD, 2015). However, according to interviewed conducted by OECD (2015) that leadership and supervision is of important but it has a slight impact on student outcomes. Further, supervision is required to foster teachers' talent to support their performance. Supervision of education is professional help and guidance for teachers in carrying out instructional duties in order to improve teaching and learning things by stimulation, coordination, and guidance continuously in order to improve the teachers' performance (Sagala, 2009). Therefore, it was emphasised that supervision is essential as it will affect teachers' motivations and capacities (OECD, 2008). There are five leadership dimension affecting student outcomes, namely; (1) Establishing goals and expectations, (2) Strategic resourcing, (3) Planning, coordinating and evaluatings teaching and the curriculum, (4) Promoting and participating in teacher learning and development, (5) Ensuring and orderly and supportive environment (Robinson, V., Hohepa, M., and Lloyd, C., 2009). According to Ministerial Decree No. 12/2007 that there are six dimensions to assess the supervisors competence, namely; (1) Personal competence, (2) Managerial supervision, (3) Academic supervision, (4) Education evaluation, (5) Research and development and, (6) Social. It is common that principals as the leader of school have always tended to focus on the administrative aspects of the assessment for teachers' certification. It is merely caused that most principals/supervisors/assessors are not ready to assess teachers, hence the process varied accross region. Developing the principals' skills will require full support from the government as principals should be able to manage teacher induction and performance 
assessment.

Teaching has become more attractive career choice as a result of certification which it comes with professional allowances. Since 2005, the government has attempted to escalate teachers' competence by issuing a regulation of minimum standard of teachers' qualification that is academic bachelor's degree. This regulation also stipulated the minimum competency standards and the certification requirement. In addition, teachers who work in remote areas will be paid an incentives. According to Ministerial Decree No.35/2010, there are 14 competency standards that should be met by teachers for their performance assessment. Professional competency plays an important role in improving teaching's quality as stipulated by the Act No. 14/2005, therefore pressure and support will result accountability and professional development for teachers.

Certified teachers usually have work ethics as it will stimulate them to improve their performance for certification purpose. Therefore, teachers who have a high work ethic will always be excited or eager to conduct their teaching and learning activities as the work ethic has become part of his life. Teachers work ethic can be used as a mainstream in the education world of Indonesia. The work ethic is the characteristics and attitudes and habits of a person doing business to meet the physical and spiritual needs as well as specific purposes (Latif, 2013). Based on the discussion above, this study wants to investigate the impact of supervision, motivation and work ethic on teachers' professional competence.

\section{Literature Review}

The relationship between supervision, motivation, work ethic and teachers' performance has been investigated by many researchers. Many recent studies have focused on profit sectors compared to non-profit sectors. Education is one of non-profit sectors which can be defined as a process of facilitating learning or transfering knowledge, and it frequently engages an educator which is called as teacher or lecturer. People sometimes focus more on the process and the students than the educators. They mostly believed that the educators have been appropriately paid, therefore, they demanded the educators to work more professionally. Basically, the educators are also paid employees in an organisation. So that, the similar treatment of human resource management practices to the profit sector employees also applies to the non-profit employees, for instance selection, training, career planning, compensation, performance appraisal, job definition and employee participation on perceived employee performance.

Competence is a trait (characteristic) and people (competent) who have the skills, power (ability), authority (authority), skills (skills), and knowledge reflected in the daily habitual action and performing daily task (Sagala, 2009; Mudlofir, 2012). Teachers' professional competence is one of important factors affecting teachers' achievement in the teaching and learning process that is caused by their academic qualification, quality and length of the teaching experience. Professional competence can be defined as knowledge, attitude and skill linked to the act. 
A profession is a job that requires specific requirements to implement them and it is supported by expertise, commitment and relevant skills (Wirawan, 2002). A person is considered as a professional if in carying out his duties, he always clung to the work ethic, the independent (free from external pressures), fast (productive), right (effective), efficient and innovative (Wisdom, 2011). Teachers can be classified as a professional teachers if they have the ability to implement number of concepts and principles, and to demonstrate number of strategies and approaches which are appropriate to the teaching and learning environment. Further, professional teachers are required to be able to motivate themselves and students to optimise their potential in terms of educational standards required (Sagala, 2009). Professionalism is affected by expertise, ability and adequate income (Sagala, 2009).

Professional competence is a substantive element of knowledge and ability to master technical skill in accord with its professionalism as prerequisite for performance assessment. Indicators or measures of teachers' performance according to Suhuri and Sukarti (2011) are ability, initiative, precisely of working hours, the quality of performance and communication. Employee performance determines the company's performance. Firms should be able to understand the importance of human resource as a significant factor in determining firms' success and sustainability. The use of knowledge, skills, experiences and abilities to perform the assigned responsibilities can be used to evaluate employees performance. Why do the firms need to evaluate employees performance? The answers may be dozens, but the things that is notably considered by the firms are an effective and efficient process which may lead to the survival and sustainability of the firms.

Employees performance can be affected by internal and external factors. Internal factors are derived from oneself, for example their motivation, their value of life and their principles. While external factors are derived from outside oneself, for example their family, their environment and their education. This study wants to investigate the impact of supervision, motivation and work ethic on teachers' professional competence, hence, supervision comes from external factors affecting teachers' performance. Supervision in education is aimed at improving the learning and teaching process and quality. Teaching and learning process will be successful if all elements within the school can work simultenously as a team work. Sagala (2009) stated that supervision in education is a form of service to generate instructional improvement, service learning and a developed curricullum. Further, it is also defined as a professional support and guidance for teachers in carrying out daily duties in order to improve teaching and learning process by using stimulation, coordination, and guidance continuously so that professional development may flourish. In addition, Purwanto (2010) asserted that supervision in education is a responsibility of principals in guiding teachers and staffs to work effectively in order to improve he teaching and learning process, hence it may impact student outcomes. Moreover, it also can be rendered as a fostering activities which is directed to correct improper process of teaching and learning therefore it will improve the quality of teaching and learning process.

Meanwhile employees' motivation is related to employees' satisfaction in which it is defined as function of the perceived relationship between what one wants from one's job and what one perceives it as offering. Wisdom (2011) suggested that motivation is the driven of an 
action. Moreover, motivation can be defined as an impulse or stimulus given to a person which may lead to an action. Motivation can be enhanced through raising the wages, providing more rewards/incentives and tighten the regulation and sanction for the person who breaks the regulation. Furthermore, Lunenburg (2000) stated that motivation is the power that comes from inside and outside of a person stimulates a person's behaviour and action. There are several aspects that influence employees' motivation as follows (1) A sense of security at workplace, (2) A fair salary, (3) A pleasant working environment, (4) A high reward performance, and (5) A fair treatment of management. Motivation is a part of human behaviour driven, and it represents the causes for people's actions, desires and needs. To create a sense of belonging therefore the employees should be valued accordingly. A good leadership, relations, compensation schemes and salary will stimulate employees to perform their duties well and in the end it will form a sense of belonging. Siswanto (2007) asserted that motivation is a state of human psychology which gives encouragement to behave and act in order to achieve satisfaction and reduce imbalances.

Further, the success of a firm depends on its employees' behaviour, and it can be related to work ethic. There are few factors affecting the effectiveness of teaching and learning process, and one of the factors is work ethics. Work ethics of teachers will be shown usually through their attitude, integrity and responsibility. Work ethics is defined as moral principles which deal with what is right and wrong including moral duty (Cherrington, 1980; Quinn, 1983; Yankelorich, \& Immerwahr, 1984; Herrera et al., 2007). In the company, work ethics relate to company's regulation which specifies the rules of conduct within the company. In general, work ethics of a person is a reflection of his values of life which depend on the environment, experiences and life-long learning (Akonti, 2013). A proper work ethics of an employees is mostly considered qualified for higher positions and responsibilities, and they will act carefully in accord with the company's regulations as their actions have a direct impact on other people within the company, and hence a constant supervision of worker is not required.

Thoifuri (2007) stated that teachers' work ethic may be achieved if; (1) Teachers have broad horisons, (2) Teachers constantly improve their knowledge, (3) Teachers' belief on what is right and wrong, (4) Teachers should think objectively in dealing with problems, (5) Teachers should have a high dedication, motivation and loyalty, (6) Teachers should be responsible for the quality and moral personality, (7) Teachers should be able to change students' attitude, (8) Teachers should no take side in any form of interest conflict, (9) Teachers should be able to excercise their classroom's material in daily activities, (10) Teachers should have more initiatives with the develompment of science and technology.

Purcell and Weber (1979) suggesting three ways to uphold a well-performed of work ethics through; (1) An appropriate code of ethics, (2) A formal appointment of ethics committee, and (3) An ethic course for management development programmes. It is common for employees to sign the code of conduct, and it is also sometimes linked to the ethical compensation and rewards. In the end, principal should also continuously encourage and publicly reward for ethical conduct, and teachers are also encouraged to report unethical practices to principal. 


\section{$\Lambda$ Macrothink}

\section{Research Methodology}

\subsection{Data}

This study employs a survey method used a structured questionnaire. The sample in this study is all teachers of SMA Muhammadiyah in East OKU, South Sumatera, Indonesia, and the total sample used for data analysis is 131 respondents. The respondents were asked to fill the questioners on August 2015. East OKU has 18 state high schools, 18 private high schools, 1 state Islamic high school (Madrasah Aliyah) and 23 private Islamic high schools. SMA Muhamamadiyah is a private Islamic School.

\subsection{Variables}

The dependent variable is teachers' professional competence and there are five indicators used in this study such as material understanding, curriculum understanding, material inter relation understanding, implementation of the material given to student, development of the study field.

The independent variables are supervision, motivation and work ethic. The indicators used for supervision variable are group supervision and individual supervision. Group supervision includes meeting orientation, teachers' meeting, discussion, workshop and experiences exhange among the teachers. Individual supervision includes class visit, class observation, personal conversation, teachers' material assessment and self assessment. The indicators used for motivation are physical needs, safety needs, society needs, respect needs and self satisfaction needs. The indicators used for work ethic are ability, initiative, precisely working hours, performance quality and communication.

\subsection{Model Analysis}

The Ordinary Least Square (OLS) is employed in this study, and the equation below is a starting point for this study to establish if supervision, motivation and work ethic have a different impact on teachers' professional competence.

$$
\begin{aligned}
& Y_{i}=\alpha+\beta_{i 1} X_{i 1}+\beta_{i 2} X_{i 2}+\beta_{i 3} X_{i 3}+u_{i} \\
& u_{i t}=\mu_{i}+\lambda_{t}+v_{i t} \\
& i=1, \ldots, N ; t=1, \ldots, T
\end{aligned}
$$

where $y_{i}$ is teachers' professional competence. $X_{i 1}$ is supervision, $X_{i 2}$ is motivation, $X_{i 3}$ is work ethic. $\mu_{i}$ denotes the unobservable individual effect, $\lambda_{t}$ denotes the unobservable time effect, and $v_{i t}$ is the remainder stochastic disturbance term. 


\section{Macrothink}

\section{Findings and Discussions}

Table 1 provides descriptive statistics and Table 2 provides correlation result. As can be seen in Table 1, The mean value of teachers' professional competence is 3.6969 with a range of 2,9000 to 4,7000 . The mean value of supervision is 3.6123 with a range of 2,6000 to 4,8000 . The mean value of motivation is 3.8041 with a range of 2,000 to 5,000. The mean value of work ethic is 3,5639 with a range of 2,6000 to 4,8000 .

Table 1. Descriptive Statistics

\begin{tabular}{|l|l|l|l|l|}
\hline & Y & X1 & X2 & X3 \\
\hline Mean & 3.696907 & 3.612371 & 3.804124 & 3.563918 \\
\hline Median & 3.600000 & 3.600000 & 4.000000 & 3.600000 \\
\hline Maximum & 4.700000 & 4.800000 & 5.000000 & 4.800000 \\
\hline Minimum & 2.900000 & 2.600000 & 2.000000 & 2.600000 \\
\hline Std. Dev. & 0.426823 & 0.528807 & 0.824611 & 0.401608 \\
\hline Skewness & 0.378563 & 0.201345 & -0.297129 & 0.356215 \\
\hline Kurtosis & 2.634174 & 2.138504 & 2.580505 & 3.128268 \\
\hline Jarque-Bera & 2.857740 & 3.655014 & 2.138522 & 2.117866 \\
\hline Probability & 0.239580 & 0.160814 & 0.343262 & 0.346826 \\
\hline Sum & 358.6000 & 350.4000 & 369.0000 & 345.7000 \\
\hline Sum Sq. Dev. & 17.48907 & 26.84515 & 65.27835 & 15.48371 \\
\hline Observations & 131 & 131 & 131 & 131 \\
\hline
\end{tabular}

As can be seen in Table 2 that the highest correlation is between supervision and motivation at 0.58 , suggesting tight supervision tend to have higher motivation. None of the correlations among explanatory variables are above 0.58 , indicating a low likelihood of multicollinearity issues arising in the OLS regressions. 


\section{1) Macrothink}

Table 2. Correlation Result

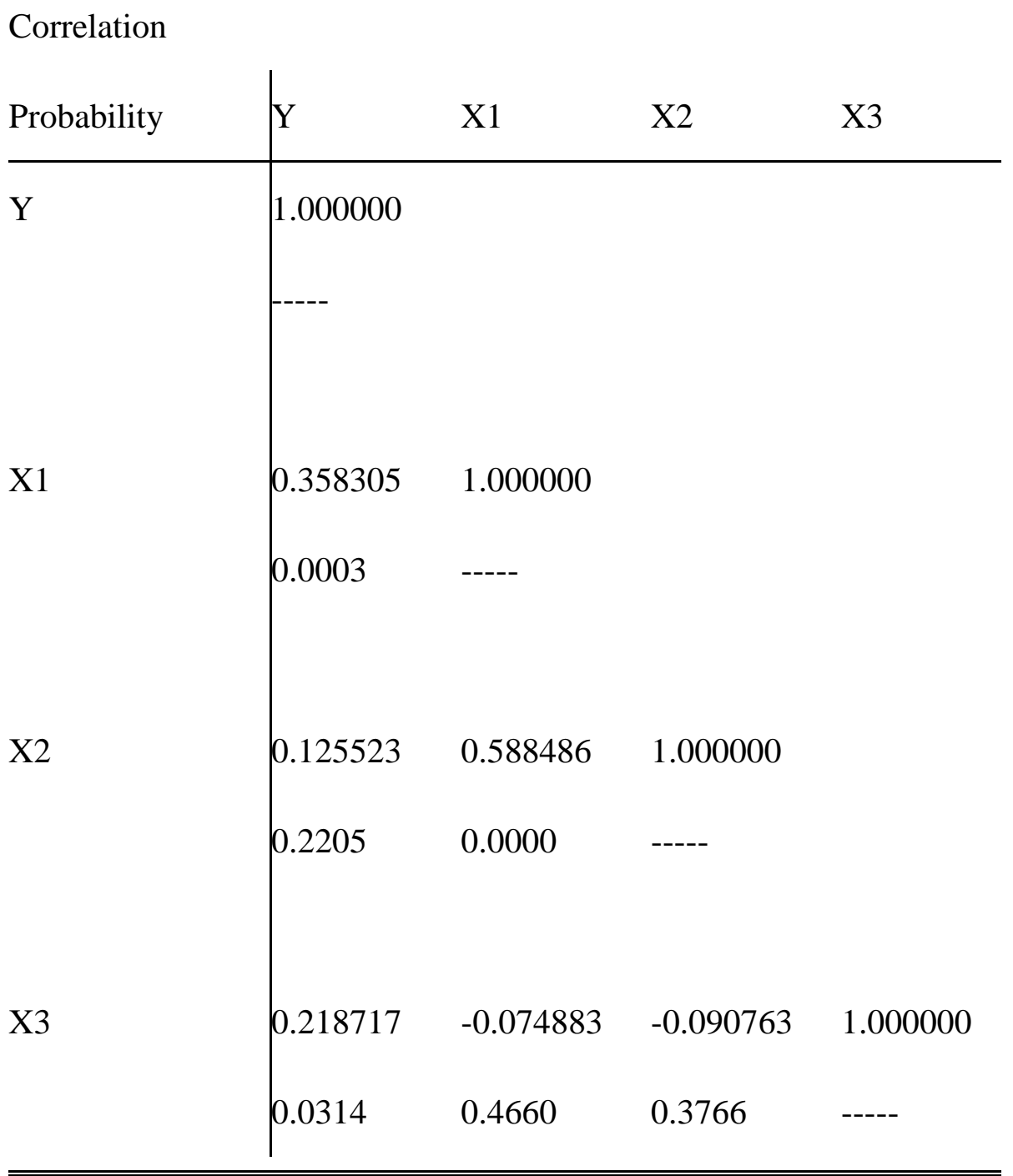

Table 3 presents the regression result, and as can be seen on the Table 3 that the coefficient for supervision is positive and significant with a coefficient value of 0,3576 and a probability value of 0,0002 , and this result suggests that an education institution who have more strict supervision will have higher teachers' professional competence. It can be concluded that the one direction of the coefficient sign for supervision and teachers' professional competence may indicate that teachers should be supervise all time as it is common in developing country with supervision at work as a part of culture. Further, the coefficient for motivation is negative and not significant with a coefficient value of $-0,0586$ and a probability value of 0,3275 , and this results suggests that motivation has no impact on teachers' professional competence. The coefficient for work ethic is positive and significant with a coefficient value of 0,2567 and a probability value of 0,0112 , and this result suggests that having higher work ethic will improve teachers' professional competence. 
Table 3. Regression Result 2016, Vol. 6, No. 1

Variable

Coefficient Std. Error t-Statistic Prob.

\begin{tabular}{lcccc}
\hline \hline X1 & 0.357616 & 0.092776 & 3.854620 & 0.0002 \\
X2 & -0.058636 & 0.059574 & -0.984256 & 0.3275 \\
X3 & 0.256783 & 0.099177 & 2.589136 & 0.0112 \\
C & 1.712974 & 0.465605 & 3.679031 & 0.0004 \\
\hline \hline & & & & \\
R-squared & 0.197377 & Mean dependent var & 3.696907 \\
Adjusted R-squared & 0.171486 & S.D. dependent var & 0.426823 \\
S.E. of regression & 0.388506 & Akaike info criterion & 0.987346 \\
Sum squared resid & 14.03713 & Schwarz criterion & 1.093520 \\
Log likelihood & -43.88630 & Hannan-Quinn criter. & 1.030278 \\
F-statistic & 7.623364 & Durbin-Watson stat & 2.083056 \\
Prob(F-statistic) & 0.000130 & & & \\
\hline \hline
\end{tabular}

Table 4 provides the heterroskedasticity test of the regression model, and the coefficient is 0,5604 suggesting that the model has homogenous variance, and ordinary least square (OLS) model is appropriately employed in this study.

Table 4. Heteroskedasticity Test: Breusch-Pagan-Godfrey

F-statistic $\quad 0.690037 \quad$ Prob. F(3,127) 0.5604

Obs*R-squared $\quad 2.112133 \quad$ Prob. Chi-Square(3) 0.5495

Scaled explained SS $1.836155 \quad$ Prob. Chi-Square(3) 0.6071 


\section{Conclusions}

It can be concluded that only supervision and work ethic have a positive and significant impact on teachers' professional competence. These results suggest that an education institution who have more strict supervision will have higher teachers' professional competence. It can be concluded that the one direction of the coefficient sign for supervision and teachers' professional competence may indicate that teachers should be supervise all time as it is common in developing country with supervision at work as a part of culture. Further, teachers who have higher work ethich will improve teachers' professional competence. Meanwhile, motivation has no impact on teachers' professional competence. Based on the findings, the authors may suggest that (1) Principals should conduct regular meetings with teachers to improve the quality of teachers, (2) Regular workshops and trainings are required for teachers to understand deeply their field, (3) Principal should regularly share knowledge to teachers, (4) Principal should assess teachers equally, (5) Change the contract type from temporary teachers to permanent teachers, (6) Teachers should have a high initiative in creating the quality of learning, (7) Teachers must be able to carry out and complete an assigned task at predefined time, (8) Teachers must also be partially responsible for the increase in school accreditation standards through increased quality or professional competence of teachers, (9) Teachers need to understand and develop the subject matter being taught and (10) Teachers should be able to apply the knowledge gained in everyday life.

\section{Limitation}

It should also be noted that this study has only covered a sample of 150 respondents from Private Islamic High Schools, in the region of East OKU, South Sumatera, Indonesia; hence, the validity of the findings interpreted in this study are limited to the scope of the data and the condition of environment for the period of the data which is 2015.

\section{Acknowledgement}

The authors are grateful to Nuril Fatah for his help in collecting the data for this study and the authors are also grateful to Abdul Basyith for his extremely useful help to improve the quality of the article. Usual disclaimers apply.

\section{References}

Act No. 74/2008. (2008). Tentang Profesional Guru dan Dosen. Jakarta, Indonesia: Departemen Pendidikan Nasional.

Act No.14/2005. (2005). Tentang Guru dan Dosen. 2005. Jakarta: Departemen Pendidikan Nasional Republik Indonesia.

Akonti, E. O. (2013). Concept of Work and Ethics. C.M.D Training Manual.

Barber, M. and Mourshed, M. (2007) How the World's Best Performing Schools Come Out on Top. London: McKinsey and Company

Cherrington, D. J. (1980). The work ethic: Working values and values that work. New York: American Management Association. 


\section{Macrothink}

International Journal of Human Resource Studies ISSN 2162-3058 2016, Vol. 6, No. 1

Herrera, C., Grossman, J. B., Kauh, T. J., Feldman, A. F., McMaken, J., \& Jucovy, L. Z. (2007). Making a difference in schools: The Big Brothers Big Sisters School-Based Mentoring Impact Study. Philadelphia: Public/Private Ventures.

Latif, A. (2013). Pengaruh Kultur Organisasi dan Kepemimpinan Kepala Madrasah terhadap Etos Kerja Guru di MAN 2 Kudus Tahun Pelajaran 2012/2013. (Tesis Master, PPS IAIN Walisongo Semarang. Indonesia). Diunduh dari: http://eprints. Walisongo.ac.id/37.

Lunenburg, O. (2000). Educational Administration. Singapura: Wadworth

Mudlofir, A. (2012). Pendidik Profesional. (cet.1). Jakarta, Indonesia: Rineka Cipta

OECD. (2008). Education at glance 2008: OECD indicatoras. Paris: OECD

OECD. (2009). Creating effective teaching and learning environments: First results from TALIS, OECD, Paris: OECD.

OECD. (2015). Education in Indonesia; Rising to the Challenge. Paris: OECD.

Permendikbud RI Nomor 5/2012. (2012). Sertifikasi Guru dalam Jabatan. Jakarta, Indonesia: Departemen Pendidikan Nasional.

Purcell T. V. and Weber, J. (1979). Institutionalizing Corporate Ethics: A Case History (New York: Presidents Association, Chief Executive Officers' Division of the American Management Association.

Purwanto, N. (2010). Administrasi dan Supervisi Pendidikan. Bandung, Indonesia: Remaja Rosdakarya.

Quinn, J. F. (1983). The work ethic and retirement. In Barbash, J., Lampman, R. J., Levitan, S. A., \& Tyler, G. (Eds.), The work ethic: A critical analysis (pp. 87-100). Madison, Wisc.: Industrial Relations Research Association.

Robinson, B., Hohepa, M., and Llyod, C. (2009). School leadership and student outcomes: Identifying what works and why: Best evidence synthesis iteration, Wellington, New Zealand: Ministry of Education, http://educationcounts.govt.nz/goto/BES

Sagala, S. (2009). Kemampuan Profesional Guru dan Tenaga Kependidikan. (cet.2). Bandung, Indonesia: Alfabeta

Siswanto. (2007). Pengantar Manajemen. (cet.3). Jakarta, Indonesia: Bumi Aksara

Suhuri., N., and Sukarti. (2011). Manajemen Pendidikan. Tim Dosen Administrasi Pendidikan UPI Bandung, Indonesia: Alfabeta.

Thoifuri. (2007). Menjadi Guru Inisiator, Rasail Media Group, Semarang.

Wirawan. (2002). Profesi dan Standar Evaluasi. Jakarta: Yayasan \& UNHAMKA PRESS.

Yankelovich, D., \& Immerwahr, J. (1984). Putting the work ethic to work. Society, 21(2), 58-76. 